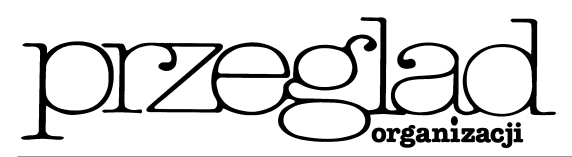

\title{
W oczekiwaniu na globalizację - ocena perspektyw rozwoju sektora bankowego w Polsce
}

https://doi.org/10.33141/po.2005.12.05

Jerzy Różański, Marek Szcześniak

\section{Ewolucja sektora bankowego w transformującej się gospodarce Polski}

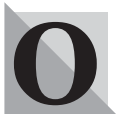

statnie piętnaście lat to okres znaczacych zmian gospodarczych i politycznych w Polsce. To także okres głębokich przemian sektora bankowego, którego zadaniem było udźwignać ciężar systemowej transformacji oraz wspierać i stabilizować trwały rozwój gospodarki. Szczególnie istotny był początkowy okres, tj. lata 1989-1991, kiedy uformowano solidne podstawy prawne do rozwoju gospodarki wolnorynkowej i efektywnego rynku finansowego. W tym czasie określono zasady powstawania i funkcjonowania banków w Polsce, zbudowano struktury Narodowego Banku Polskiego (NBP) oraz wdrożono podstawowe instrumenty wykorzystywane przez bank centralny do kształtowania polityki pieniężnej. Wiodąca rola NBP w procesie kształtowania się polskiego sektora bankowego jest niezaprzeczalna. Stworzenie w stosunkowo krótkim okresie podstawowych mechanizmów rynku finansowego umożliwiło szybki rozwój gospodarki, zwłaszcza małych i średnich przedsiębiorstw, które uzyskały dostęp do kapitału, a co ważniejsze, uzyskały gwarancje stabilności i pewności otoczenia prawno-ekonomicznego.

W krótkim czasie udało się stworzyć ramy systemu bankowego, rozumianego nie tylko w kategoriach podmiotowych, ale także jako zestaw uregulowań prawnych określających zasady funkcjonowania banków, ich wzajemne powiązania i stosunki z otoczeniem. Ustalona została także rola NBP w zakresie sprawowania nadzoru nad bankami oraz ścieżka dalszego rozwoju rynku finansowego i harmonizacji prawa bankowego. Niezależnie od opcji politycznej, wszyscy dziś doceniają sukces tego pierwszego okresu transformacji, który wyprowadził nasz kraj na pozycję lidera procesu przemian gospodarczych w Europie Srodkowowschodniej ${ }^{1}$.

Do dalszego rozwoju polskiej bankowości oraz wypracowania dzisiejszych standardów prowadzenia działalności bankowej przyczyniły się przede wszystkim dwa podstawowe czynniki:

- stopniowe otwieranie się polskiego sektora bankowego dla kapitału zagranicznego, oraz

- proces integracji Polski z Unią Europejską, a następnie członkostwo naszego kraju w tej międzynarodowej strukturze.

Aktywność kapitału zagranicznego we wchodzeniu na polski rynek usług bankowych warunkowana była
Przegląd Organizacji, Nr 12 (791), 2005, ss. 19-23 www.przegladorganizacji.pl Towarzystwo Naukowe Organizacji i Kierownictwa (TNOiK)

ściśle przez politykę banku centralnego, decydującego o dopuszczeniu do działalności na rynku krajowym banków zagranicznych bądź z udziałem kapitału zagranicznego, zgodnie z ówczesną oceną potrzeb polskiego sektora bankowego. Z tego historycznego juz punktu widzenia można wyróżnić kilka etapów otwierania polskiego sektora bankowego dla kapitału zagranicznego.

Pierwszy etap wchodzenia kapitału zagranicznego do polskiego systemu bankowego obejmował lata 1990-1991. Polityka podatkowa rządu w początkach lat 90. ub. wieku stworzyła uprzywilejowana pozycję dla banków zagranicznych. Wiązało się to z zachętą kierowaną do inwestorów zagranicznych, aby mimo wysokiego wówczas ryzyka inwestowali w nasz rynek i przyczyniali się do napływu tak potrzebnej wiedzy, technologii i kapitału. Z perspektywy czasu najwięcej zyskali ci inwestorzy, którzy uwierzyli wtedy w sukces gospodarki wolnorynkowej w Polsce. Nie tylko nie musieli ponosić żadnych dodatkowych kosztów związanych z licencją, ale korzystając z ulgi podatkowej, nowe spółki szybko zaczęły wypracowywać zyski. Była to swego rodzaju premia za odwage i ryzyko, jakiego się podjęły oraz efekt doskonałej pozycji wyjściowej do zwiększania swego udziału w tworzącym się wówczas rynku.

W połowie 1992 roku nastąiła zmiana polityki licencyjnej NBP wobec banków zagranicznych, która zapoczątkowała drugi etap w rozwoju polskiego sektora bankowego trwający do końca 1994 r. W tym czasie ujawnił się kryzys polskiego systemu bankowego, jako skutek m.in. nie dość wstrzemięźliwej polityki licencjonowania nowych banków, zbyt liberalnej polityki kredytowej oraz słabego wyszkolenia personelu bankowego. Do dziś trwają spory, czy był to wynik zbyt agresywnej, na tym etapie rozwoju rynku, polityki NBP, czy też naturalny i nieunikniony wówczas objaw, będący konsekwencją słabości gospodarki i nieudolności urzędników odpowiedzialnych za reformę systemu prawnego. Doprowadziło to do zasadniczej zmiany strategii NBP, w której uznano, że dopuszczenie na polski rynek silnych kapitałowo banków zagranicznych mogłoby stworzyć poważne zagrożenie konkurencyjne dla banków polskich. W świetle tej opinii przystąpiono do umacniania krajowego sektora bankowego poprzez liczne działania konsolidacyjne, restrukturyzację i prywatyzację banków zagrożonych bankructwem.

Od tego momentu można mówić o trzecim okresie w polityce dopuszczania kapitału zagranicznego do 
polskiego rynku usług bankowych, trwajaccym od końca 1994 do roku 1999. W tym okresie banki zagraniczne zainteresowane ekspansją na terenie naszego kraju, zostały zobowiązane do przejęcia całości bądź pakietu kontrolnego tego polskiego banku, który w danym momencie przeżywał kłopoty finansowe i wymagał pomocy ze strony silnego inwestora.

Ostatni etap otwierania się polskiego rynku finansowego na kapitał zagraniczny jest związany właśnie z procesem integracyjnym i według niektórych opinii właściwie rozpoczął się nawet wcześniej, bo już w 1996 roku, kiedy Polska została przyjęta do OECD (Organizacja Współpracy Gospodarczej i Rozwoju) i zobowiązała się do akceptacji założeń, celów i regulacji z tym związanych. W praktyce nasze członkostwo w OECD oznaczało powstrzymywanie się od wprowadzania nowych ograniczeń (restrykcji) i stopniową liberalizacje rynku finansowego. Proces integracji z UE wymusił także unifikację regulacji bankowych z przepisami unijnymi, bliższą współpracę NBP z Europejskim Bankiem Centralnym, zwłaszcza na płaszczyznach harmonizacji prawa, realizacji efektywnej polityki pieniężnej i kursowej oraz utrzymania stabilności finansowej sektora bankowego. Do realizacji tych celów NBP korzystał z przysługujących mu instrumentów, jak np. rezerwa obowiązkowa, operacje otwartego rynku, operacje kredytowo-depozytowe NBP, czy też zarządzanie polityka stóp procentowych i polityką kursową. NBP podejmował bądź promował wiele inicjatyw zmierzajaccych do podniesienia bezpieczeństwa sektora bankowego, w tym np. do powstania i rozwoju systemu informacji międzybankowej (m.in. Bankowy Rejestr Niesolidnych Klientów, Biuro Informacji Kredytowej, Baza Dokumentów Zastrzeżonych czy też ostatnio Biuro Informacji Gospodarczej) oraz wdrożenia instrumentów zapobiegajacych „praniu brudnych pieniędzy”. Ostatnie lata to także okres zwiększonej ingerencji NBP w procesy zarządzania ryzykiem działalności bankowej, utożsamiany nie tylko z przejmowaniem unijnych standardów nadzorczych (m.in. zaleceń Komitetu Bazylejskiego i odpowiadającej im Dyrektywy Kapitałowej), ale znajdujacy także odzwierciedlenie w modyfikacji przepisów rachunkowości bankowej oraz rozszerzeniu zakresu obowiązkowej sprawozdawczości, zapewniajacej zwiększona kontrolę sytuacji finansowej poszczególnych jednostek.

\section{Problem umiędzynarodowienia polskich banków}

$\mathbf{O}$ roli sektora bankowego w budowaniu gospodarki wolnorynkowej niech świadczy fakt, że w 2003 r. udział banków w aktywach całego rynku finansowego wynosił aż 77,9\%, a w początkowych latach transformacji systemowej był on nawet znacząco większy. Skutkiem przemian własnościowych, które nasiliły się pod koniec lat 90 ., było zmniejszenie liczby banków komercyjnych - z 87 w roku 1993, do 54 na koniec $2004 \mathrm{r}$. Wzrosła także koncentracja sektora: udział aktywów 5 największych banków osiagną $50,2 \%$, a w ogólnej kwocie depozytów zgromadzonych przez banki aż 56,7\%. Na koniec ubiegłego roku na Warszawskiej Giełdzie Papierów Wartościowych były notowane akcje 14 banków krajowych i 1 zagranicznego, a udział banków krajowych w kapitalizacji giełdy wyniósł 33,9\%. Przewagą kapitału pol-
Tab. 1. Udział kapitału zagranicznego w krajowym sektorze bankowym

\begin{tabular}{|l|c|c|}
\hline $\begin{array}{c}\text { Kraj } \\
\text { pochodzenia } \\
\text { kapitału* }\end{array}$ & $\begin{array}{c}\text { Liczba } \\
\text { kontrolowa- } \\
\text { nych banków }\end{array}$ & $\begin{array}{c}\text { Udział } \\
\text { w aktywach } \\
\text { sektora (w \%) }\end{array}$ \\
\hline Niemcy & 12 & $18,9 \%$ \\
\hline Włochy & 2 & $11,3 \%$ \\
\hline USA & 6 & $8,6 \%$ \\
\hline Holandia & 2 & $7,9 \%$ \\
\hline Belgia & 18 & $5,1 \%$ \\
\hline Pozostałe & 44 & $15,8 \%$ \\
\hline $\begin{array}{l}\text { Ogółem kapitał } \\
\text { zagraniczny }\end{array}$ & & $67,6 \%$ \\
\hline
\end{tabular}

* według pierwotnego podmiotu dominującego

Źródło: Narodowy Bank Polski. Dane wg stanu z 31 grudnia $2004 \mathrm{r}$.

skiego charakteryzowało się 13 (spośród 54) krajowych banków komercyjnych, z tego dwa bezpośrednio kontrolowane przez skarb państwa. Pozostałe banki były nadzorowane bezpośrednio bądź pośrednio przez inwestorów zagranicznych, reprezentujących 17 krajów (przede wszystkim Niemcy, Włochy i USA) i kontrolujących 67,6\% aktywów sektora. Dla porównania, banki z większościowym udziałem kapitału zagranicznego stanowia $75 \%$ aktywów całego sektora bankowego krajów Europy Środkowowschodniej i średnio zaledwie $24 \%$ w krajach unijnej piętnastki (UE15).

Należy podkreślić, że banki kontrolowane przez kapitał zagraniczny wypracowały w 2004 r. 4964,5 mln zł zysku netto, co stanowiło 72,8\% zysku wypracowanego przez wszystkie banki komercyjne działające w Polsce.

Jednym z najczęściej analizowanych problemów związanych z transformacją banków w Polsce było zagadnienie, czy oddanie przez NBP kontroli nad krajowym sektorem bankowym inwestorom zagranicznym było słusznym posunięciem i jaki może mieć ono wpływ na przyszłość naszej gospodarki. Czy sektor bankowy, jako podstawa rynku finansowego, będzie w stanie spełniać właściwie swą rolę i nie tylko przynosić wartość swoim właścicielom, ale też wspierać i stabilizować rozwój kraju i w ten sposób przyczyniać się do poprawy poziomu życia całego społeczeństwa? Zastanówmy się także, czy słuszna jest opinia NBP, że wysoki udział kapitału zagranicznego, to przede wszystkim efekt niezbędnej prywatyzacji i restrukturyzacji banków, które znalazły się w trudnej sytuacji finansowej. Niezbędnej zarówno z punktu widzenia ekonomicznego, jak i społecznego, jeśli weźmiemy pod uwagę specyficzny charakter banków - instytucji mających przynosić zyski swoim właścicielom, a jednocześnie podlegających nadzorowi bankowemu, który musi dbać o bezpieczeństwo i wiarygodności całego sektora.

Nikt zapewne nie jest $\mathrm{w}$ stanie przesądzić, jakie byłyby efekty innych decyzji NBP; należy jednak gwoli prawdy dodać, że podobną ścieżkę rozwoju obrano także w innych krajach naszego regionu, gdzie udział kapitału zagranicznego jest jeszcze większy niż w Polsce, przekraczając w Czechach i w Słowenii poziom 
90\%. Oznacza to, że na sytuację i rozwój sektora bankowego w krajach środkowoeuropejskich, duży wpływ będą miały procesy i decyzje podejmowane przez właścicieli banków i ich strategie wobec tej części Europy. Spróbujmy dokonać oceny inwestycji zagranicznych w sektor bankowy i zastanowić się, jaka jest przyszłość naszego sektora bankowego na zintegrowanym rynku unijnym. Jakie są szanse i zagrożenia stojące przed krajowymi bankami. Rozważania te poprowadzimy na dwóch płaszczyznach: regulacyjnej, związanej $\mathrm{z}$ procesem dostosowania polskich przepisów do dyrektyw unijnych, a przede wszystkim do Nowej Dyrektywy Kapitałowej opartej na zaleceniach Nowej Umowy Kapitałowej Komitetu Bazylejskiego oraz ekonomicznej, dotyczącej pozycji konkurencyjnej krajowego sektora bankowego, a także szans i zagrożeń związanych z jego funkcjonowaniem na międzynarodowym rynku usług finansowych. Te dwie płaszczyzny zwykle traktuje się rozłącznie, jednak z uwagi na fakt, że kształt regulacji prawnych określa stopień liberalizacji rynku oraz pozycję jego poszczególnych uczestników, uwzględnienie tego dualizmu wydaje się uzasadnione.

Z uwagi na członkostwo Polski w Unii Europejskiej, podstawowym czynnikiem warunkującym kształt regulacji prawnych sa dyrektywy unijne. Od 1 maja 2004 r. banki z siedzibą w UE bez przeszkód i dodatkowych formalności mogą prowadzić działalność na terenie Polski w formie oddziału (wcześniej wymagało to zezwolenia ministra finansów i w praktyce odmawiano wydania takiego zezwolenia podmiotom zagranicznym). Uwzględniając fakt, że działając $w$ formie instytucji kredytowej podlegaja one rygorom dotyczacym limitów koncentracji i poziomu współczynnika wypłacalności w układzie skonsolidowanym (tylko w ograniczonym stopniu podlegają rygorom przepisów obowiązujących w Polsce) oraz biorąc pod uwagę wielokrotnie większą bazę kapitałową zagranicznych banków, oznacza to, że mogą one prowadzić w Polsce działalność kredytowa na znacznie większą skalę niż dotychczas. Niższe koszty kapitału regulacyjnego (z uwagi na możliwość zastosowania zaawansowanych metod oceny adekwatności kapitałowej i preferencyjnych, niższych wag ryzyka dla swoich lokalnych ekspozycji) umożliwiają bardziej agresywną politykę kredytową i sprzyjają uzyskiwaniu wyższej rentowności z zainwestowanych kapitałów. Wszystko to przemawia za tym, że w najbliższych latach będziemy mieć do czynienia z kolejną fazą przekształceń własnościowych, zwiększoną ekspansją kapitału zagranicznego i dalszym wzrostem konkurencji w tej branży.

Tezę tę potwierdza również atrakcyjność polskiego sektora bankowego dla inwestorów zagranicznych. Jest to największy rynek spośród 10 państw przyjętych do UE w maju $2004 \mathrm{r}$. Według danych na koniec 2003 r. udział naszego rynku w tej grupie stanowił ponad $30 \%$. Należy jednak zaznaczyć, że aktywa bankowe dziesięciu nowych krajów UE (UE10) - ok. 300 banków z łączną wartością aktywów netto na poziomie ok. 350 mld EUR - stanowią zaledwie 3\% łacznej wartości aktywów rozszerzonej Unii Europejskiej (UE25). Największe różnice w stosunku do krajów Europy Zachodniej ujawniają się przy porównaniu wskaźników wyrażających skalę działalności banko- wej. Relacja wartości aktywów sektora bankowego w stosunku do wartości PKB krajów Europy Środkowowschodniej wynosi 74\%: najmniej, bo tylko $33 \%$ w Rumunii oraz niespełna 40\% na Litwie, najwięcej natomiast - 97\% w Czechach i aż 105\% w Chorwacji. W Polsce wskaźnik ten wynosi zaledwie $60 \%$, co stanowi mniej niż $1 / 3$ wartości osiaganej w strefie euro (201\%). Dla porównania, spośród krajów UE15, najwyższe wskaźniki obserwujemy w Irlandii (461\%) oraz Holandii $(421 \%)$. Podobne relacje występuja w odniesieniu wartości portfela kredytowego do wartości PKB (34\% dla nowych krajów i 102\% w strefie euro), gdzie znów Polska notuje wynik niższy od przeciętnej w regionie - zaledwie $31 \%$. W Holandii wskaźnik ten osiągnął na koniec 2003 r. aż 238\%, a w Irlandii niewiele mniej, bo ponad $216 \%{ }^{2}$. Tak znaczace różnice pomiędzy nowymi krajami UE a strefą euro wynikają m.in. ze stopnia rozwoju gospodarczego oraz poziomu życia w poszczególnych krajach. Dla przykładu, średni roczny dochód w nowych krajach UE wynosi niecałe 3000 euro, niespełna 15\% średniego dochodu uzyskiwanego przez dorosłego obywatela krajów strefy euro (23 700 euro). Bezpośrednio przekłada się to na chłonność rynku usług i produktów bankowych, czego potwierdzeniem jest niemal identyczna proporcja pomiędzy przeciętną kwotą depozytu w obydwu regionach (nowe kraje 1404 euro i strefy euro 13004 euro).

\section{Rentowność banków w "starych" i „nowych" krajach UE}

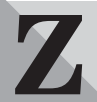

uwagi na dużą konkurencję oraz wysoki poziom „ubankowienia” społeczeństwa i nasycenia rynków lokalnych, coraz więcej zagranicznych instytucji bankowych zaczyna poszukiwać nowych źródeł zysku i z coraz większą uwagą przygląda się krajom naszego regionu, gdzie wskaźniki dynamiki rozwoju sektora bankowego są ponaddwukrotnie wyższe od przeciętnej w strefie euro. $\mathrm{O}$ atrakcyjności rynku nowych krajów UE dla zagranicznych inwestorów świadczą nie tylko wskaźniki wzrostu działalności bankowej, ale także wyższa, w porównaniu do krajów euro, rentowność banków w tej części Europy.

Niemal trzykrotnie wyższa wartość wskaźnika ROA uzyskiwana przez banki z regionu Europy Środkowowschodniej ma swoje źródło przede wszystkim w relatywnie wyższych rynkowych stopach procentowych, determinujacych przeciętny poziom oprocentowania kredytów. Relacja ta niewiele się zmienia nawet, gdy zysk netto zostanie skorygowany o wartość rezerw, które zwłaszcza w Polsce sa znacznie większe niż przeciętna $\mathrm{w}$ regionie i krajach strefy euro. To wynik tzw. trudnych kredytów, pozostałości po latach transformacji i budowy gospodarki wolnorynkowej. Słabo wypadamy także pod względem kosztów działalności bankowej, zwłaszcza porównując rok 2003, gdzie wskaźnik na poziomie $75 \%$ znacznie przekracza średnią dla krajów nowych $64 \%$ i strefy euro $61 \%$. Oceny nie zmienia nawet fakt, że za nami znajduja się Niemcy (71\%) oraz Francja i Austria (po 69\%), jeśli uwzględnimy, że są to najgorsze wskaźniki ze wszystkich krajów UE, a liderzy osiagaja wskaźniki na poziomie zbliżonym do 50\% (np. Irlandia, Portugalia, Dania czy Hiszpania). 
Tab. 2. Dochodowość sektora bankowego w nowych krajach UE (CEE) i krajach strefy euro (SE)*

\begin{tabular}{|l|c|c|c|c|}
\hline \multirow{2}{*}{} & \multicolumn{2}{|c|}{$\begin{array}{c}\text { Stopa zwrotu z kapitalów } \\
\text { po opodatkowaniu }\end{array}$} & \multicolumn{2}{c|}{$\begin{array}{c}\text { Stopa zwrotu z aktywów } \\
\text { po opodatkowaniu }\end{array}$} \\
\cline { 2 - 5 } & $\mathbf{2 0 0 2}$ & $\mathbf{2 0 0 3}$ & $\mathbf{2 0 0 2}$ & $\mathbf{2 0 0 3}$ \\
\hline EU - 15 (Top 50) & $10 \%$ & $11 \%$ & $0,4 \%$ & $0,4 \%$ \\
\hline EU CEE - 5 (Top 31)** & $13 \%$ & $12 \%$ & $1,2 \%$ & $1,1 \%$ \\
\hline Polska & $5 \%$ & $5 \%$ & $0,6 \%$ & $0,4 \%$ \\
& & $(17,5 \% * *)$ & & $2,1 \%$ \\
\hline Węgry & $17 \%$ & $20 \%$ & $1,8 \%$ & $1,6 \%$ \\
\hline Słowacja & $14 \%$ & $16 \%$ & $1,6 \%$ & $1,0 \%$ \\
\hline Czechy & $13 \%$ & $17 \%$ & $0,9 \%$ & n.a. \\
\hline Słowenia & $16 \%$ & $13 \%$ & $2,0 \%$ & \\
\hline
\end{tabular}

* Średnia arytmetyczna; ** 9 banków z Polski, 8 z Węgier, 5 z Czech, 4 ze Słowacji i 5 ze Słowenii; *** Dane za rok 2004 dla wszystkich banków komercyjnych w Polsce.

Źródło: dane publikowane przez Banki Narodowe, Europejski Bank Centralny oraz na podstawie Banking in CEE, opracowania Departamentu Ekonomicznego Banku Austria Creditanstalt, Wiedeń, kwiecień 2004.

Tab. 3. Wskaźniki sprawności działania banków CEE i SE (stan na koniec 2003 r.)*

\begin{tabular}{|l|c|c|c|c|c|c|}
\hline \multirow{2}{*}{} & \multicolumn{2}{|c|}{$\begin{array}{c}\text { Przychody odsetkowe } \\
\text { jako \% aktywów) }\end{array}$} & $\begin{array}{c}\text { Koszty kredytowych } \\
\text { rezerw celowych } \\
\text { (\% aktywów) }\end{array}$ & \multicolumn{2}{c|}{$\begin{array}{c}\text { Wskaźnik } \\
\text { koszty / przychody }\end{array}$} \\
\cline { 2 - 7 } & $\mathbf{2 0 0 2}$ & $\mathbf{2 0 0 3} * *$ & $\mathbf{2 0 0 2}$ & $\mathbf{2 0 0 3} *$ & $\mathbf{2 0 0 2}$ & $\mathbf{2 0 0 3} * *$ \\
\hline EU - 15 (Top 50) & $1,8 \%$ & $1,6 \%$ & $0,3 \%$ & $0,3 \%$ & $69 \%$ & $61 \%$ \\
\hline EU CEE - 5 (Top 31) & $3,4 \%$ & $3,1 \%$ & $0,7 \%$ & $0,4 \%$ & $63 \%$ & $64 \%$ \\
\hline Polska & $3,1 \%$ & $2,8 \%$ & $1,4 \%$ & $0,8 \%$ & $64 \%$ & $75 \%$ \\
\hline Węgry & $4,3 \%$ & $4,0 \%$ & $0,3 \%$ & $0,3 \%$ & $58 \%$ & $54 \%$ \\
\hline Słowacja & $3,2 \%$ & $3,5 \%$ & $0,1 \%$ & $0,0 \%$ & $64 \%$ & $58 \%$ \\
\hline Czechy & $2,5 \%$ & $2,9 \%$ & $0,2 \%$ & $-1,0 \%$ & $69 \%$ & $60 \%$ \\
\hline Słowenia & $4,4 \%$ & n.a. & $1,5 \%$ & n.a. & $59 \%$ & n.a. \\
\hline
\end{tabular}

* Średnia arytmetyczna; ** 9 banków z Polski, 8 z Węgier, 5 z Czech, 4 ze Słowacji i 5 ze Słowenii.

Źródło: dane publikowane przez Banki Narodowe, Europejski Bank Centralny oraz na podstawie Banking in CEE, opracowania Departamentu Ekonomicznego Banku Austria Creditanstalt, Wiedeń, kwiecień 2004.

\section{Procesy globalizacyjne i integracyjne w sektorze bankowym w Polsce}

W ydaje się, że procesy globalizacyjne nie ominą naszego sektora bankowego. Wszędzie tam, gdzie decyduje wolny rynek, należy oczekiwać swobodnego przepływu kapitału w kierunku inwestycji przynoszących wyższy dochód, przy zachowaniu akceptowalnego poziomu ryzyka. Zakończony okres transformacji, integracja z Unią Europejską oraz spodziewane rozszerzenie strefy wspólnej waluty na nowe kraje UE, pozwalają inwestorom zagranicznym $\mathrm{z}$ optymizmem patrzeć na kolejne inwestycje w naszym regionie. Postęp cywilizacyjny znakomicie ułatwia realokację kapitału, wiedzy i pracy w kierunku krajów rozwijających się, charakteryzujących się dużą chłonnością rynku i o wiele większą dynamiką rozwoju. Globalizacja przenika do wszelkich przejawów aktywności gospodarczej, co każe nam przychylić się do opinii NBP, że bardziej zachowawcza polityka banku centralnego spowodowałaby, że obecnie - w warunkach wolnej konkurencji - nasze banki nie byłyby w stanie konkurować z potentatami rynku europejskiego, co w efek- cie doprowadziłoby do pełnej utraty ich lokalnej tożsamości. Opóźniony rozwój sektora bankowego mógłby stać się hamulcem procesów transformacji gospodarczej, zwiększając dystans dzielący nas obecnie od krajów Europy Zachodniej.

Dominujaca rola kapitału zagranicznego w krajowym sektorze bankowym zasługuje dziś na nieco inną ocenę niż jeszcze kilkanaście lat temu. W świecie, w którym znikają wszelkie bariery i ograniczenia, swobodny przepływ kapitału oraz wolność decyzji inwestycyjnych nieuchronnie będą prowadzić do integracji poszczególnych rynków. To prawda, że sektor bankowy nie może być traktowany jak inne działy gospodarki, ale oznacza to tylko to, że niezbędna jest wspólna polityka przedstawicieli nadzoru bankowego, większa przejrzystość rynku i dyscyplina rynkowa. Odpowiedzia na te potrzeby jest właśnie Nowa Umowa Kapitałowa Komitetu Bazylejskiego, której celem jest dostosowanie przepisów nadzorczych do zmieniającego się otoczenia oraz rozpowszechnienie najlepszych praktyk rynkowych w celu zwiększenia bezpieczeństwa i stabilności rynków finansowych. Specyfiką projektu bazylejskiego jest to, że stymuluje on procesy konsolidacji wiedzy i kapitału w ra- 
mach całej grupy bankowej. Możliwość wdrożenia najbardziej efektywnych metod zarządzania ryzykiem w wyżej notowanych spółkach-matkach uwarunkowana jest realizacją minimalnych wymagań kapitałowych przez wszystkie spółki zależne. Wymaga to ujednolicenia metod i standardów w ramach całej grupy i sprzyja wymianie doświadczeń pomiędzy poszczególnymi podmiotami grupy. Jak pokazuje praktyka, najlepszą formą współpracy jest taka, w której banki $\mathrm{z}$ wybranych krajów dokonuja transferu wiedzy jedynie w określonych obszarach merytorycznych, a za zarządzanie wiedzą odpowiada ta spółka, która w danej dziedzinie ma największe doświadczenie. W ten sposób tworzy się swoista sieć eksperckich powiązań i zwiększa się efektywność wykorzystania dostępnej wiedzy i zasobów. Transfer doświadczeń z poszczególnych krajów pobudza rozwój organizacji i tworzy jej przewagę konkurencyjną ${ }^{3)}$.

Niezależnie od wyniku naszej oceny, pewne jest, że stoimy dziś - podobnie jak większość krajów europejskich - przed kolejna falą konsolidacji sektora bankowego. Co prawda, wbrew oczekiwaniom specjalistów, fuzja BRE Banku SA z kolejnymi kandydatami nie doszła do skutku, to jednak wydaje się, że zapowiadane połączenie drugiego i trzeciego banku w Polsce (banków Pekao SA i BPH SA) i powstanie w efekcie najsilniejszego banku w regionie będzie bodźcem dla innych inwestorów i motywacją do umacniania swej pozycji w naszym regionie. Powstanie tak dużej instytucji pozwoli jej osiagnąć masę krytyczną, warunkująca wykorzystanie efektu skali i wysoką rentowność działania. Doprowadzi to $\mathrm{z}$ całą pewnością do zmiany warunków konkurencji na naszym rynku i zmusi innych uczestników do aktywnych działań. Podobne procesy dotknęły już wiele innych branż, np. samochodową, farmaceutyczną, odzieżową, czy elektroniczną, a teraz przyszła kolej na sektor finansowy. Przy tym porównaniu ciekawe wydaje się, czy sektor bankowy uniknie tych błędów, których doświadczyły inne branże. Praktyka dowodzi bowiem, że wiele inwestycji nie zostało poprzedzonych gruntowną analizą szans i zagrożeń. W pogoni za konkurencją i chęcią zysku otwierano zbyt wiele inwestycji w coraz bardziej odległych zakątkach świata, nie doceniając kosztów wejścia na nowe rynki zbytu i przeniesienia działalności do nowych fabryk. W efekcie, jak podają światowe statystyki, aż $60 \%$ wszystkich fuzji i przejęć nie przynosi zakładanych efektów ${ }^{4}$. Zbytnie rozproszenie działalności, czy to w ujęciu geograficznym czy funkcjonalnym, prowadzi do zmniejszenia efektywności procesów zarządczych, nie sprzyja redukcji kosztów i nie pozwala szybko i właściwie reagować na potrzeby rynku. Mimo to coraz więcej analityków przepowiada ekspansję międzynarodowych grup finansowych, skupiajacych w jednej organizacji komplet usług i produktów finansowych adresowanych do wszystkich segmentów klientów.

Jak dowodzą specjaliści z firmy A.T. Kearney5), do sprawnego przeprowadzenia fuzji niezbędne są jasna strategia oraz doświadczenie menedżerów kierujacych projektem. Jeden nieodpowiedni ruch może się okazać bardzo kosztowny w skutkach. Aby znaleźć najlepsze potencjalne fuzje na europejskim rynku finansowym, specjaliści ci przebadali ponad 50 dużych grup kapitałowych, szukając dla nich najkorzystniejszych partnerów do fuzji oraz mierząc skutki potencjalnych fuzji, w rozumieniu pozycji rynkowej połączonych instytucji. Wnioski płynące z tej analizy wskazują, że stosunkowo najniższy poziom koncentracji występuje na rynku bankowości detalicznej. Kolejnymi obszarami możliwych działań konsolidacyjnych są fuzje banków inwestycyjnych i korporacyjnych oraz lączenie branży bankowej i ubezpieczeniowej.

Dokonując analizy możliwości wykorzystania szans, jakie stoją przed sektorem bankowym w Polsce, trzeba zwrócić uwagę na aktualną sytuację finansową kraju i kondycję naszych banków na tle unijnych konkurentów. Choć do czołówki nadal nam daleko, perspektywy dla naszego kraju i sektora bankowego są korzystne. Możliwości rozwoju sektora zależne będą od tempa rozwoju gospodarki oraz wzrostu zamożności społeczeństwa, co pośrednio wpłynie także na zwiększenie aktywności gospodarstw domowych i małych przedsiębiorstw oraz wzrost popularności nowoczesnych usług i produktów bankowych. Na tym polu wciąz jest wiele do zrobienia. Silna presja konkurencyjna, powodująca rozwój nowych innowacyjnych produktów, i zmieniające się otoczenie prawne wymuszać będą nieustanny rozwój nowych koncepcji i narzędzi, coraz lepiej dopasowanych do potrzeb i warunków funkcjonowania nowoczesnych banków. Rozpowszechnieniu nowoczesnych standardów zarządzania ryzykiem sprzyja konstrukcja Nowej Umowy Kapitałowej, wymuszająca integrację procesów w ramach całych grup bankowych, ale zdaniem autorów nowe przepisy nadzorcze i związane $\mathrm{z}$ tym przemiany wewnętrzne nie rozwiążą wszystkich problemów nękających polski rynek finansowy. Do gruntownej poprawy sytuacji niezbędna będzie zmiana systemu podatkowego, transformacja polskiego sądownictwa, skrócenie procesu rejestracji własności oraz liberalizacja zasad zakładania dzialalności gospodarczej. Palącym problemem staje się także reforma kodeksów cywilnego i postępowania cywilnego, zwłaszcza w obszarze możliwości egzekwowania długów po wyroku sądowym. Na działalność banków i całego systemu finansowego wpływają bowiem regulacje przyjęte w innych sektorach gospodarki oraz sprawność funkcjonowania podmiotów gospodarczych - potencjalnych klientów banków i ryn$\mathrm{ku}$ finansowego w Polsce.

prof. dr hab. Jerzy Różański Marek Szcześniak - doktorant Katedra Zarządzania Przedsiębiorstwem Uniwersytet Łódzki

\section{PRZYPISY}

1) Jest to opinia zgodna zarówno wśród ludzi praktyki, jak i środowiska naukowego. Można znaleźć jej potwierdzenie m.in. [w:] W.L. JAWORSKI, Banki: rynek, operacje, polityka, Poltext, Warszawa 2000, s. 14.

2) $\mathrm{W}$ ocenie pominięto Luksemburg, gdzie udział aktywów sektora bankowego w PKB przekracza $2500 \%$, a relacja portfela kredytowego do PKB wynosi (na 31 grudnia 2003 r.) $563 \%$

3) R. KRAJEWSKI, Na wspólnej ścieżce, „Gazeta Bankowa”, nr 36, 5-11 września 2005, s. 17.

4) M. TEBEAU, Making the Most of Globalization, „Gazeta Bankowa", nr 36/2005, s. 40-41.

5) Making Connections, w opracowaniu Consolidation Strategies for European Financial Services Firm, 2004. 